\title{
An Economist's Influence on Health Policy
}

\author{
Peter Zweifel
}

Published online: 27 August 2014

(c) Springer International Publishing Switzerland 2014

Being a citizen of a small country (Switzerland), my influence on policy was bound to be limited and mostly indirect. The biggest indirect influence probably has been through the textbooks Gesundheitsökonomie [1] in German-speaking countries and Health Economics [9] internationally. Otherwise, only six instances come to my mind where my work might have had a direct impact.

The first was a popular publication prepared for Interpharma, the public relations arm of the Swiss pharmaceutical industry. In 1981, it launched a series entitled Studien zur Gesundheitsökonomie (Studies in Health Economics), which emulated the Office of Health Economics in London. The first issue described the health maintenance organization (HMO) as a possible innovation in Swiss healthcare [12]. The reaction by the media and policy makers at the time was thoroughly negative, arguing that there was no need to introduce 'cheap Wild West medicine' in Switzerland. The scientific community neglected the piece too, although we arguably were the first on the European continent to write about what one would call 'managed care' today. It simply had the wrong pedigree, being financed by 'big pharma'.

However, it did get the attention of someone in the Swiss federal administration who was looking for economists to write a script for the reform of the law on health insurance. Two attempts at reforming this law (which dated from 1911) had failed, but Mr Cotti, the federal minister in charge, wanted to try again. In 1987, he commissioned me

This article is part of the Topical Collection on The influence of Health Economists on Health Policy

P. Zweifel ( $\square)$

University of Zurich, Zurich, Switzerland

e-mail: peter.zweifel@uzh.ch (along with three other economists, working in competition) to come up with such a script [4]. Admittedly, I failed to see the potential for full deregulation at the time; only 25 years later did I realize that the first-best solution would have been to let competing social health insurers charge risk-based premiums, while premium subsidies (which were already in existence then) would be targeted to those who are both poor and high risk [8]. (Poor but low-risk and rich but high-risk citizens can pay for health insurance themselves.) This insight was due to the realization that risk adjustment would never be fully incentive compatible, driven home again recently [7]. To the surprise of the Swiss medical profession, the bill passed a popular referendum in late 1995 to become law in 1996. It was Janus-faced, containing regulatory and pro-competitive elements. However, since then, its regulatory side has been strengthened, while its pro-competitive elements have been pushed back.

The third instance of influence was in the context of this new law. In 1989, I organized a study trip to the USA for a delegation comprising the Chief Executive Officers (CEOs) of Swiss health insurers and Mr Cotti's chief of staff. One of the CEOs had noticed my work on bonus options for no claims in health insurance $[3,15]$. He wanted bonus options to become an alternative to the HMO, which had become popular with policy makers by then (see above). Indeed, the law of 1996 vests social health insurers (rather than the government, as, for example, in Germany) with the right to launch innovations, provided the innovation promises to be efficiency enhancing. This study trip led to the introduction of bonus options into Swiss social health insurance; however, the federal administration surreptitiously slashed a $10 \%$ 'solidarity surcharge' on the premium, causing them to attain a market share of a mere $1 \%$. 
In 2005, a popular initiative calling for doing away with competing social health insurers in favor of a national health insurance scheme was successfully launched. Its promoters mainly came from the French-speaking part of Switzerland. They were inspired by the Canadian model as implemented in Québec province. Knowing this, I organized another study trip in 2006 with the aim of comparing the provision of healthcare in Canada and the USA. One of the sites visited was the City hospital of oil- and gas-rich Calgary. Our guide pointed to the reception hall, asking us to estimate the average time the 50-some patients would have to wait before seeing a physician (rather than a triage nurse). From experience with Swiss polyclinics, we came up with no more than $3 \mathrm{~h}$, only to be told that the true figure was $8 \mathrm{~h}$. A policy maker we met afterwards conceded that "Yes, maybe Calgary might invest a bit more in its healthcare facilities." He was also candid enough to remind us that $90 \%$ of the Canadian population lives within $4 \mathrm{~h}$ of driving from the US border. Therefore, anyone loath to wait drives south, pays a second time (in addition to his or her tax), and contributes to the 'excessive' gross domestic product (GDP) health share in the USA while helping to lower the Canadian one. In a debate on Swiss TV later in 2006, I had occasion to cite this experience-which left the representatives in favor of the popular initiative speechless (it was later defeated at the polls by a two-third majority).

These four instances of possible influence all concern Switzerland, a rather irrelevant country. However, in one case, the addressee was even the US Government itself. In the early 1990s, I received a major research grant, 'Economic analysis of aging'. This research led to a series of publications on long-term care (LTC) and its insurance, with emphasis on intergenerational moral hazard, meaning that the presence of LTC insurance may undermine children's incentives to provide informal care [5, 13, 14]. This research caught the interest of the American Enterprise Institute (AEI) in Washington DC, which invited me to write up guidelines for (US) policy with regard to the elderly [6]. This publication earned me an invitation to the AEI's 1997 annual meeting - and a picture featuring Alan Greenspan (the then Governor of the Federal Reserve) and myself. However, my impact on US health policy remains doubtful.

Sixth and last, in 2005, the World Bank initiated a major project revolving around private voluntary health insurance in low-income countries. Mark Pauly of the Wharton School (University of Pennsylvania) and I were commissioned to provide its economic underpinnings [2, 10, 11]. Mark opted for the demand module, while I found myself stuck with the supply side. This proved quite a challenge because most of the existing research focuses on the behavior of for-profit property-liability insurers as the suppliers of insurance coverage, yet private health insurance in low-income countries is dominated by nonprofit mutual schemes. The theory of these organizations had to be pretty much developed from scratch. It focused on the determinants of the so-called loading, which is the component of the premium that is not paid back to consumers in the guise of benefits. Therefore, the loading for administrative expense, risk bearing, and profit constitutes the true price of insurance; the remainder of an insurer's premium income is used for paying claims, amounting to redistribution between consumers with and without a claim. From the insurer's point of view, the present value of expected future payments for medical care constitutes the crucial part of its marginal cost of enrolling an additional person. Applying the famous 'marginal cost equal price' rule, Mark and I argued for risk-rated premiums, combined with targeted subsidies designed to make them affordable to consumers who are both high risk and low income. However, the whole idea of having private voluntary insurance play a role in low-income countries was strongly resisted not only by the World Health Organization and the International Labor Organization but also by some in the World Bank itself. This resistance caused the conference for the launch of the pertinent publication to be held at the Wharton School in Philadelphia rather than in Washington DC. However, it did not prevent the book Private Voluntary Health Insurance in Development. Friend or Foe? [2, 10, 11] from becoming a best seller for the World Bank. Of course, it still remains to be seen whether governments in Asia and Africa will muster the courage to break away from the 'National Health Service' model to which they have been clinging for decades.

In conclusion, there is precious little evidence suggesting that my 30 years of endeavor in health economics will leave much of a trace in health policy, be it in my home country or abroad. But then, I firmly believe in the division of labor between academics (whose task is to come up with analysis of the status quo and-possibly-suggestions for reform) and politicians, who face the big challenge of finding a majority for any reform proposal they deem worthwhile.

Disclosures There is no relevant conflict of interest and no funding was received for the writing of this commentary.

\section{References}

1. Breyer F, Zweifel P, Kifmann M. Gesundheitsökonomie (Health economics). 6th ed. Berlin: Springer; 2012.

2. Pauly MV, Scheffler RM, Zweifel P, Preker AS, Bassett M. Private health insurance in developing countries. Health Aff. 2006;25(2):369-79. 
3. Zweifel P. Bonus systems in health insurance: a microeconomic analysis. Health Policy. 1987;7:273-88.

4. Zweifel P. Neuordnung der Krankenversicherung (Reforming Health Insurance), Advisory Report to the Swiss Federal Department of the Interior. Bern: EDMZ; 1988.

5. Zweifel P. Providing for long-term care: insurance vs. trust saving, Geneva papers on risk and insurance. Issues Pract. 1996;21(79):284-92.

6. Zweifel P. Guidelines for policy and a proposal for long-term care for the elderly. In: American Enterprise Institute for Policy Research, editor. Financing long-term care. Washington DC; 1997. p. 1-21.

7. Zweifel P. The present state of health economics: a critique and an agenda for the future (Editorial). Eur $\mathrm{J}$ Health Econ. 2013;14(4):569-71.

8. Zweifel P, Breuer M. The case for risk-based premiums in public health insurance. Health Econ Policy Law. 2006;1(2):171-88.

9. Zweifel P, Breyer F, Kifmann M. Health economics. 2nd ed. New York: Springer; 2009.
10. Zweifel P, Krey BB, Tagli M. Supply of private voluntary health insurance in low-income countries. In: Preker AS, et al., editors. Private voluntary health insurance in development-friend or foe?. Washington: The World Bank; 2007. p. 55-113.

11. Zweifel P, Pauly MV. Market outcomes, regulation, and policy recommendations. In: Preker AS, et al., editors. Private voluntary health insurance in development-friend or foe?. Washington: The World Bank; 2007. p. 115-45.

12. Zweifel P, Pedroni G. Die "Health Maintenance Organization"Die Alternative im Gesundheitswesen? (The HMO-the alternative for health care?). Basel: Pharma Information; 1981.

13. Zweifel P, Strüwe W. Long-term care insurance and bequests as instruments for shaping intergenerational relationships. J Risk Uncertain. 1996;12(1):1265-76.

14. Zweifel P, Strüwe W. Long-term care insurance in a two-generation model. J Risk Insur. 1997;65(1):13-32.

15. Zweifel P, Waser O. Bonus options in health insurance. Dordrecht: Kluwer; 1992. 